\title{
SEDIMENTARY RECORD OF TERMINAL CRETACEOUS ACCRETIONS IN ECUADOR: THE YUNGUILLA GROUP IN THE CUENCA AREA
}

\author{
Etienne JAILLARD(1), Peter BENGTSON(2), Martha ORDOÑEZ(3), Wilmer VACA(4), Annie \\ DHONDT( $\dagger)$, Johnny SUÁREZ(3) and Jorge TORO $(5,4)$.
}

(1) IRD-UR 154, LMTG, 14 av. Edouard BELIN, 31400 Toulouse, France now at: LGCA, Maison des Géosciences, BP 53, 38041 Grenoble Cedex 09, France. Etienne.Jaillard@ujf-grenoble.fr

(2) Geologisch-Paläontologisches Institut, Universität Heidelberg, Im Neuenheimer Feld 234, D-69120 Heidelberg, Germany. bengtson@uni-hd.de

(3) Petroproducción, Centro de Investigaciones Geológicas-Guayaquil, km 6,5 vía a la Costa, Guayaquil, Ecuador. cigg@ elconet.net

(4) Escuela Politécnica Nacional, Ladrón de Guevara s/n, PO Box 17-01-2759, Quito, Ecuador. wilmerirvaca@hotmail.com

(5) Petroproducción, Av. 6 de Diciembre y G. Cañero, Casilla 17-01-1006, Quito, Ecuador. jedutoro@ hotmail.com

\begin{abstract}
A reappraisal of the "Late Cretaceous Yunguilla Formation" of the Cuenca area made it possible to define four distinct formations, correlatable with those of southwestern Ecuador. A mid to late Campanian marine transgression (Jadán Fm) is overlain by quartz-rich conglomerates of fan-delta to turbiditic fan environment (Quimas Fm) of latest Campanian-earliest Maastrichtian age, which are interpreted as evidence of the accretion of a first oceanic terrane (San Juan). Disconformable, arkosic turbidites and cherts (Tabacay Fm) of early Maastrichtian age are thought to represent the erosion of the newly accreted oceanic terrane. A major unconformity of late Maastrichtian age, caused by the accretion of a second oceanic terrane (Guaranda), is followed by the deposition of quartz-rich micaceous shelf sandstones (Saquisili Fm) of Paleocene age. A third accretion event (late Paleocene) is recorded in coastal Ecuador. Each accretion event correlates with the uplift and erosion of the Eastern Cordillera, and with a sedimentary hiatus in the eastern areas. This suggests that in Ecuador, accretion of oceanic terranes contributed to the build-up of the Andes through tectonic underplating of low-density material, and that the eastern areas did not behave as a flexural foreland basins during late Cretaceous-Paleogene times.
\end{abstract}

\section{Introduction}

The Andes of Ecuador differ from the Central Andes by the presence of mafic magmatic terranes (Goossens and Rose, 1973; Gansser, 1973), interpreted as oceanic fragments accreted during Late Cretaceous and Eocene times (Feininger and Bristow, 1980; Lebrat et al., 1987; Daly, 1989; Reynaud et al., 1999; Kerr et al., 2002). More recently, some authors (Arculus et al., 1999; Guillier et al., 2001; Jaillard et al., 2002; Toro and Jaillard, 2005) proposed that the accreted oceanic material has been tectonically underplated and constitutes the crustal root of the Andes of Ecuador.

In order to constrain the date, processes and consequences of the accretions on Andean tectonics, we studied the dominantly clastic sediments coeval with the accretions (Late Cretaceous-Eocene), located on the western edge of the continental margin, i.e. in the present-day Cordillera of Ecuador.

\section{Geological setting}

The coast and Western Cordillera of Ecuador are made up of terranes of oceanic origin, whereas the continental Andean margin comprises the deformed Eastern Cordillera (Litherland et al., 1994) and the 
Subandean Zone and Oriente Basin (Jaillard, 1997; Fig. 1). In northern and central Ecuador $\left(1^{\circ} \mathrm{N}-2^{\circ} \mathrm{S}\right)$, the Western and Eastern Cordilleras are separated by the Inter-Andean Valley, infilled by products of the Neogene to Quaternary volcanic arcs (Lavenu et al., 1996; Hungerbüler et al., 2002). Farther south $\left(2^{\circ} \mathrm{S}-\right.$ $5^{\circ} \mathrm{S}$ ), the tectonic boundary between the allochtonous, oceanic units and the autochtonous continental margin is located west of the Western Cordillera (Fig. 1), and the well-defined Inter-Andean Valley vanishes.

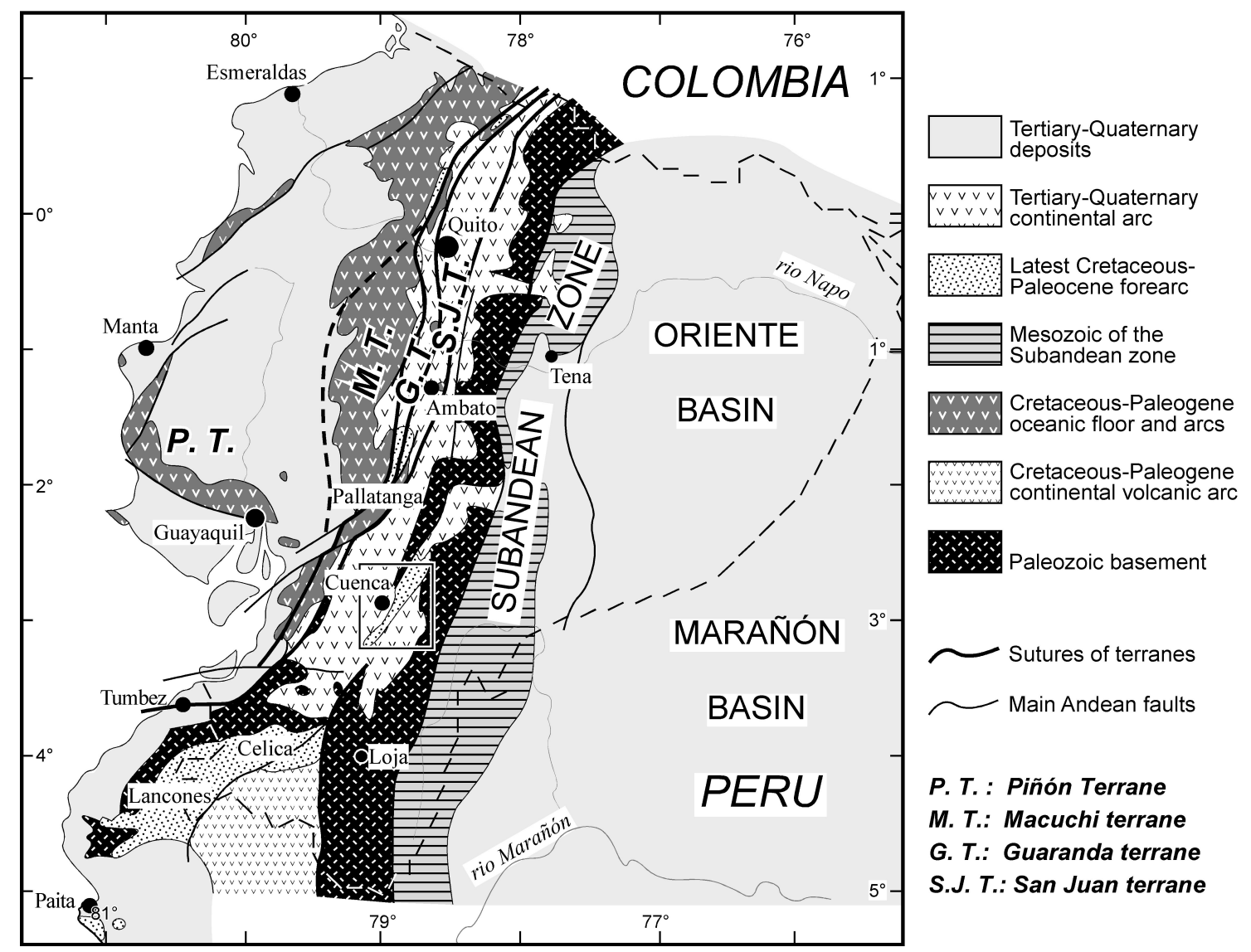

Fig. 1: Structural sketch of Ecuador, and location of Figure 2.

Bold lines represent sutures bounding oceanic terranes.

The Cuenca area $\left(\approx 3^{\circ} \mathrm{S}\right)$ is situated on the western edge of the Eastern Cordillera (Litherland et al., 1994), and is bounded to the west by uplifted Tertiary arc volcanic piles, the basement of which is most probably continental, as evidenced by crystalline outcrops west of Cuenca (Dunkley et al., 1998; Pratt et al., 1998). This relative depression received thick, marine to subaerial deposits during the Mid Miocene, and subsequent compressional deformations were controlled by major NE-trending faults (Bristow, 1980; Noblet et al., 1988; Hungerbühler et al., 2002). As for the Celica area of southwestern Ecuador (Kennerley, 1973; Jaillard et al., 1996; 1999), the basement of the Tertiary deposits of the Cuenca area is mainly represented by Jurassic-Paleozoic metamorphic rocks, as well as by Cretaceous-Paleogene sedmentary deposits (Bristow, 1980; Litherland et al., 1994; Hungerbühler et al., 2002). The latter sediments are the goal of the present study (Fig. 2).

\section{Previous work}

The name "Yunguilla Formation" was introduced by Thalmann (1946) for a succession of black shales and sandstones, dated with foraminifers as Maastrichtian, exposed northwest of Quito. Since then, comparable Maastrichtian sediments were identified and dated with microfossils in the Western Cordillera of Ecuador, between Quito and Cuenca (Tschopp, 1948; Sigal, 1969; Kehrer and Kehrer, 1969; Faucher et al. 1971; Bristow, 1973; Jaillard et al., 2004), in southwestern Ecuador (Loja area; Sigal, 1969) and locally in the subandean zone (Limón area; Faucher et al., 1971). Later, many rocks referred to as the Yunguilla Formation have been dated as Paleocene or Eocene, and new Paleogene units have been defined (Faucher et al., 1971; Henderson, 1981; Egüez and Bourgois, 1986; Santos and Ramírez, 1986; Hughes et al., 1999; 
Jaillard et al., 2004).

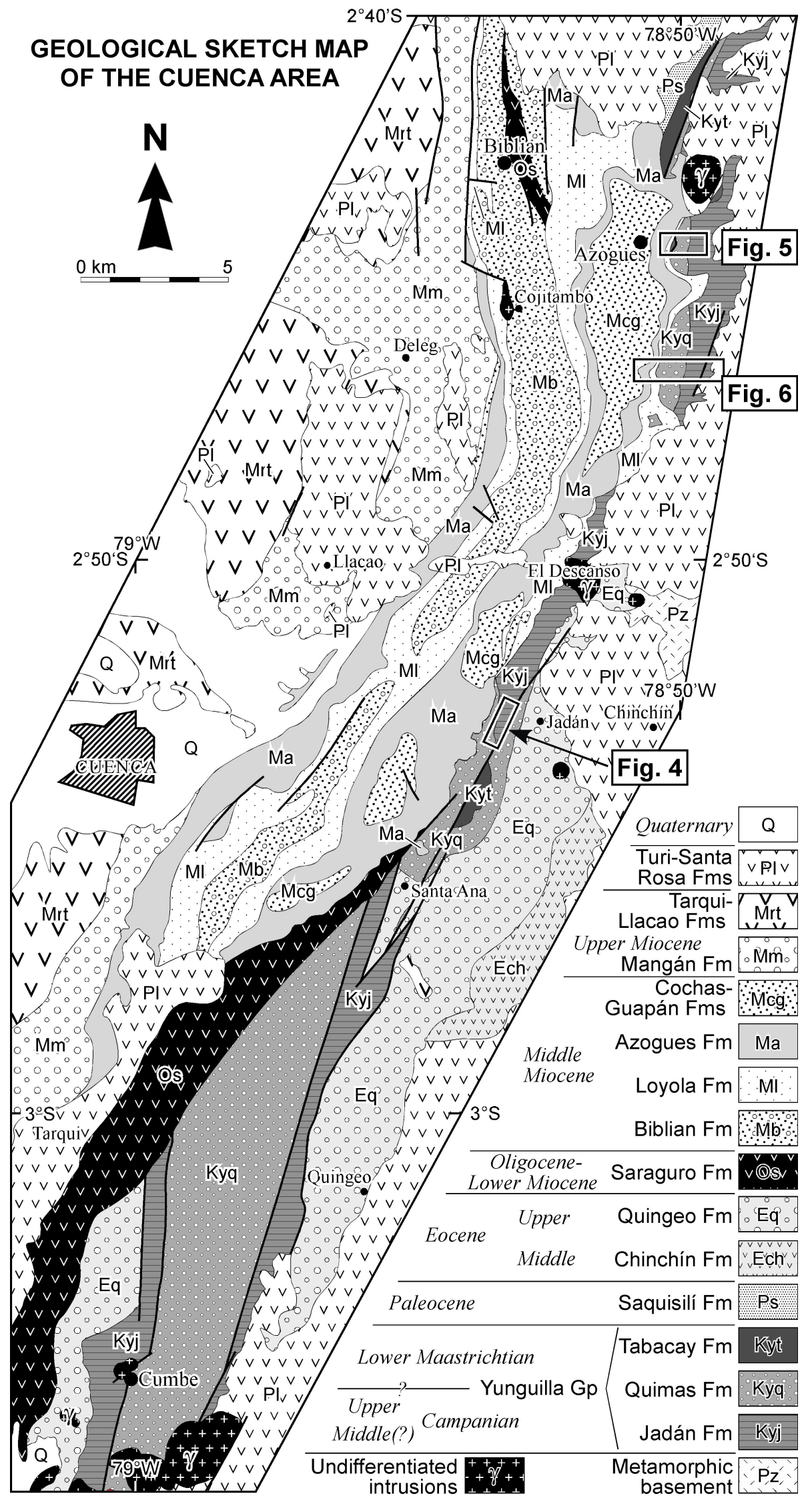

Fig. 2: Geological Map of the Cuenca area, compiled from Bristow (1980), Noblet et al. (1988), Steinmann (1997), Dunkley et al. (1998), Pratt et al. (1998), Hungerbühler et al. (2002) and personnal observations.

Figures 4, 5 and 6 are located. 
In the Cuenca-Azogues area (Fig. 2), Bristow (1980) considered that the "Yunguilla Formation" rests on Cretaceous volcanic rocks. The latter, however, were subsequently dated by fission tracks analysis as Oligocene (Steinmann, 1997). The Late Cretaceous-Paleogene succession seems to constitute the basement of the Miocene intermontane basin, and rests on metamorphic rocks of the continental basement of Ecuador (Noblet et al., 1988; Steinmann, 1997; Dunkley and Gaibor, 1998; Pratt et al., 1998; Hungerbühler et al., 2002; Vaca, 2005). The "Yunguilla Formation" crops out East of Cumbe, Cuenca and Azogues, along a NNE-trending belt (Fig. 2). Further north, in the Pallatanga area, the "formation" is tectonically associated with accreted oceanic terranes, whith which it is assumed to have been in stratigraphic contact (McCourt et al., 1998; Hughes et al., 1999; Jaillard et al., 2004). To the southwest, the uppermost Cretaceous succession rests unconformably on Paleozoic to middle Cretaceous rocks of the forearc zones of southern Ecuador and northwestern Peru (Olsson, 1944; Jaillard et al., 1998; 1999).

In the Cuenca-Azogues area, Faucher et al. (1971) and Bristow (1973) identified three distinct lithologic units.

1. Cherts and greywackes, commonly silicified, yielded scarce and poorly preserved fossils referred to the Maastrichtian. They considered this unit to be the lower part of the "Yunguilla Formation" (but see below under Tabacay Formation).

2. Poorly consolidated shales with limestone lenses and arkosic sandstones beds, were dated with microfossils as Maastrichtian. These rocks were interpreted as the upper part of the "Yunguilla Formation" (Faucher et al., 1971). Ammonites were collected from these units and were assigned to the lower Maastrichtian (Bristow, in Bristow and Hoffstetter, 1977).

3. According to Bristow (in Bristow and Hoffstetter, 1977), marine shales and limestone lenses of the Cumbe area, referred to as the "Yunguilla Formation", grade upwards into continental, volcanogenic red beds. From the "Yunguilla Formation", Bristow (in Bristow and Hoffstetter, 1977) reported one Inoceramus sp. and an unidentified ammonite, and Pratt et al. (1997) collected the ammonites Hoploscaphites sp. and Baculites sp. of Maastrichtian age. From the overlying fine-grained red beds, Bristow (in Bristow and Hoffstetter, 1977) collected Paleocene molluscs, and Pratt et al. (1997) collected Pterotrigonia sp., known in the Maastrichtian of Peru.

In the Cuenca area, the "Yunguilla Formation" is overlain by Middle Eocene volcanics (Chinchín Formation, approximately $43 \mathrm{Ma}$ ) and unconformable continental volcanogenic red beds of Mid to Late Eocene age (Quingeo Formation, 42-34 Ma) (Steinmann, 1997; Hungerbühler et al., 2002). Pratt et al. (1997) correlated the continental volcanogenic red beds of the Cumbe area with the Quingeo Formation (Fig. 2), defined and dated further northeast by Steinmann (1997).

\section{Stratigraphy and depositional interpretation of the Late Cretaceous-Paleocene rocks of the Cuenca area}

Based on geological surveys and study of stratigraphic sections, combined with exhaustive fossil collecting, we have subdivided the rock succession formerly ascribed to the "Yunguilla Formation" into four formations ranging in age from the mid or late Campanian to the Paleocene (Fig. 3). We here introduce the Yunguilla Group, which comprises the middle (?) to upper Campanian Jadán Formation, the conglomeratic Quimas Formation, and the lower Maastrichtian Tabacay Formation. The Yunguilla Group is overlain by the Paleocene Saquisilí Formation, formerly included in the "Yunguilla Formation".

Jadán Formation (middle(?) to upper Campanian)

Although it corresponds to the lithologic unit 2 described above, the Jadán Formation is the lowest unit of the Yunguilla Group. It consists mainly of shales and marls, with thin limestone and arkosic sandstone beds. The base of the formation is not exposed. Since metamorphic rocks crop out just east of the Yunguilla Group, the latter most probably overlies unconformably the continental margin (Steinmann, 1997), as observed further north (Vaca, 2005). The lowermost part of the Jadán Formation is strongly deformed and probably acted as a décollement level.

The Jadán Formation is best exposed along the El Descanso-Jadán road (Loma Tunasloma), which is proposed as the type section, and East of Azogues (Santa Bárbara). It is also exposed southeast of Santa Ana, northeast of El Descanso and around Cumbe (Fig. 2). The 500-800 m thick formation can be subdivided into three lithologic units ("members"). 


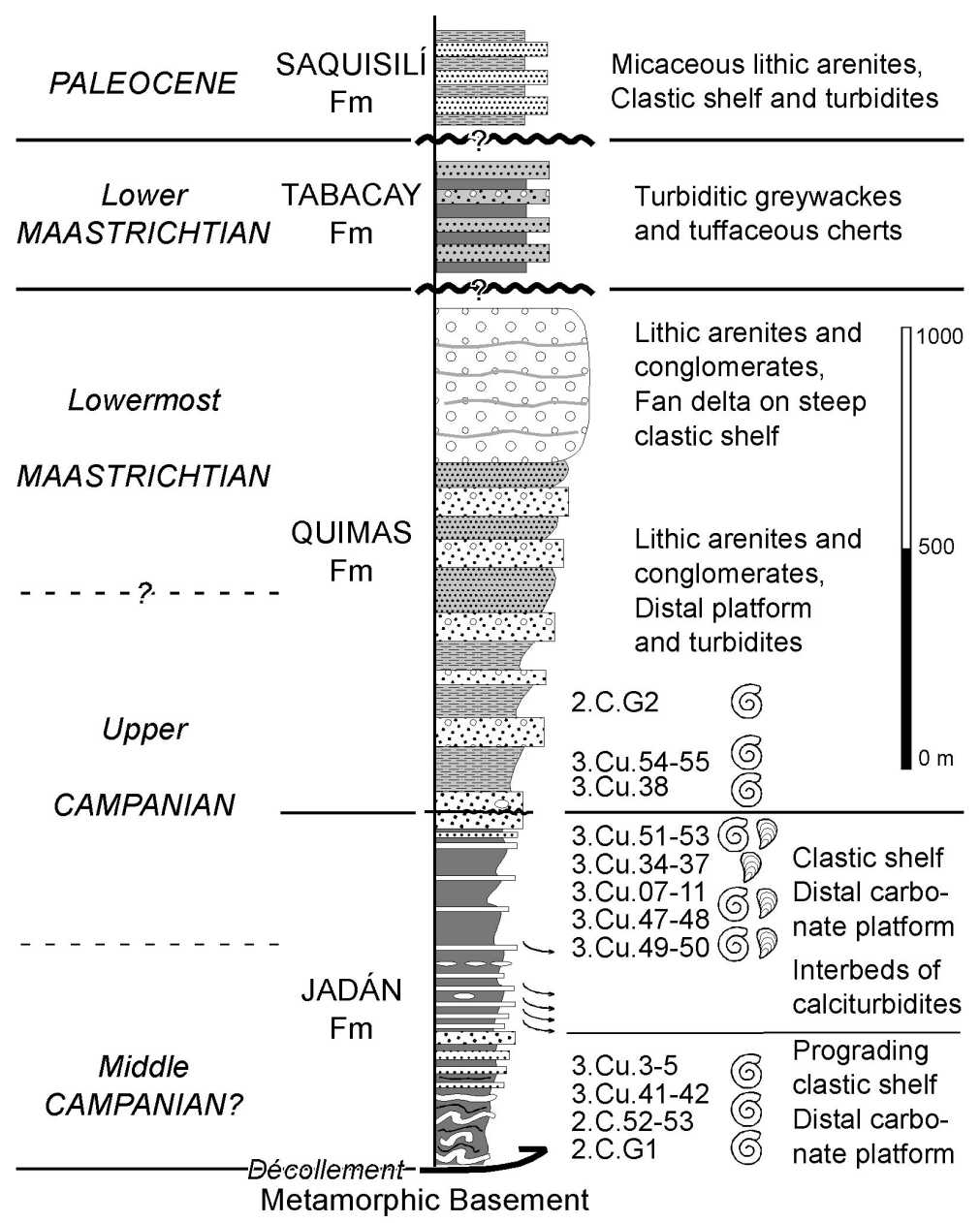

Fig. 3: Synthetic lithological succession of the upper Cretaceous-Paleocene series of the Cuenca area.

- The lower part of the formation is made up of loose, silty shales and marls with thin beds of dark micritic limestones and arkosic to lithic, fine- to medium-grained sandstones. The limestones are locally nodular and sandy. The sandstones are locally rich in micas, and cementation is generally calcareous. Local bioclastic limestones are interpreted as distal turbidites. The succession is composed of 100-200 m thick, coarsening-, thickening- and shallowing-upward sequences. Abundance of the bivalve Pinna sp. indicates a moderate paleodepth $(\leq 100 \mathrm{~m})$, whereas common wood fragments suggest proximity to land. Ammonites collected along the El Descanso-Jadán road were indentified as Diplomoceras sp. (upper CampanianMaastrichtian) (sample [02.C.52], Table 1) and Glyptoxoceras sp. (Santonian-Maastrichtian) or Neoglyptoxoceras sp. (lower-middle Campanian) ([02.C.53, 02.C.G1, 03.Cu.05], Table 1).

\begin{tabular}{|c|c|c|c|}
\hline Sample & \multicolumn{2}{|c|}{ Location } & $\begin{array}{c}\text { Stratigraphic } \\
\text { unit }\end{array}$ \\
\hline $\begin{array}{l}02 . C .52 \\
\text { 02.C.53 } \\
\text { 02.C.G1 } \\
\text { 03.Cu.05 }\end{array}$ & \multirow[t]{2}{*}{$\begin{array}{l}\text { Jadán road, western } \\
\text { slope of the ridge divi- } \\
\text { ding río Jadán and que- } \\
\text { brada Huangarcucho }\end{array}$} & $\begin{array}{l}73580-968350 \\
73560-968330 \\
73570-968340 \\
73530-968310\end{array}$ & $\begin{array}{l}\text { Jadán Fm } \\
\text { Lower unit }\end{array}$ \\
\hline $03 . \mathrm{Cu} .03$ & & $73520-968290$ & Middle Jadán Fm \\
\hline $\begin{array}{l}\text { 02.Cu. } 07 \\
02 . \text { Cu. } 08 \\
02 . C u .09 \\
03 . C u .10 \\
\text { 03.Cu. } 11 \\
\text { D. Iza } \\
\end{array}$ & $\begin{array}{l}\text { Loma Tunasloma, } \\
\text { ridge between río Jadán } \\
\text { and quebrada Huangar- } \\
\text { cucho }\end{array}$ & $\begin{array}{l}73470-968250 \\
73460-968240 \\
73460-968240 \\
73450-968230 \\
73450-968230 \\
73460-968250 \\
\end{array}$ & $\begin{array}{l}\text { Jadán Fm } \\
\text { Upper unit }\end{array}$ \\
\hline $\begin{array}{l}02 . C . G 2 \\
02 . C .52 \\
02 . C .53 \\
02 . C . G 1\end{array}$ & \begin{tabular}{|l|} 
Southeast of Antonio \\
Borero \\
Santa Barbara, east of \\
Azogues
\end{tabular} & $\begin{array}{l}74040-969310 \\
73580-968350 \\
73560-968330 \\
73570-968340\end{array}$ & Quimas Fm \\
\hline
\end{tabular}

Table 1: Origin and location of the fossil samples cited in the text. 


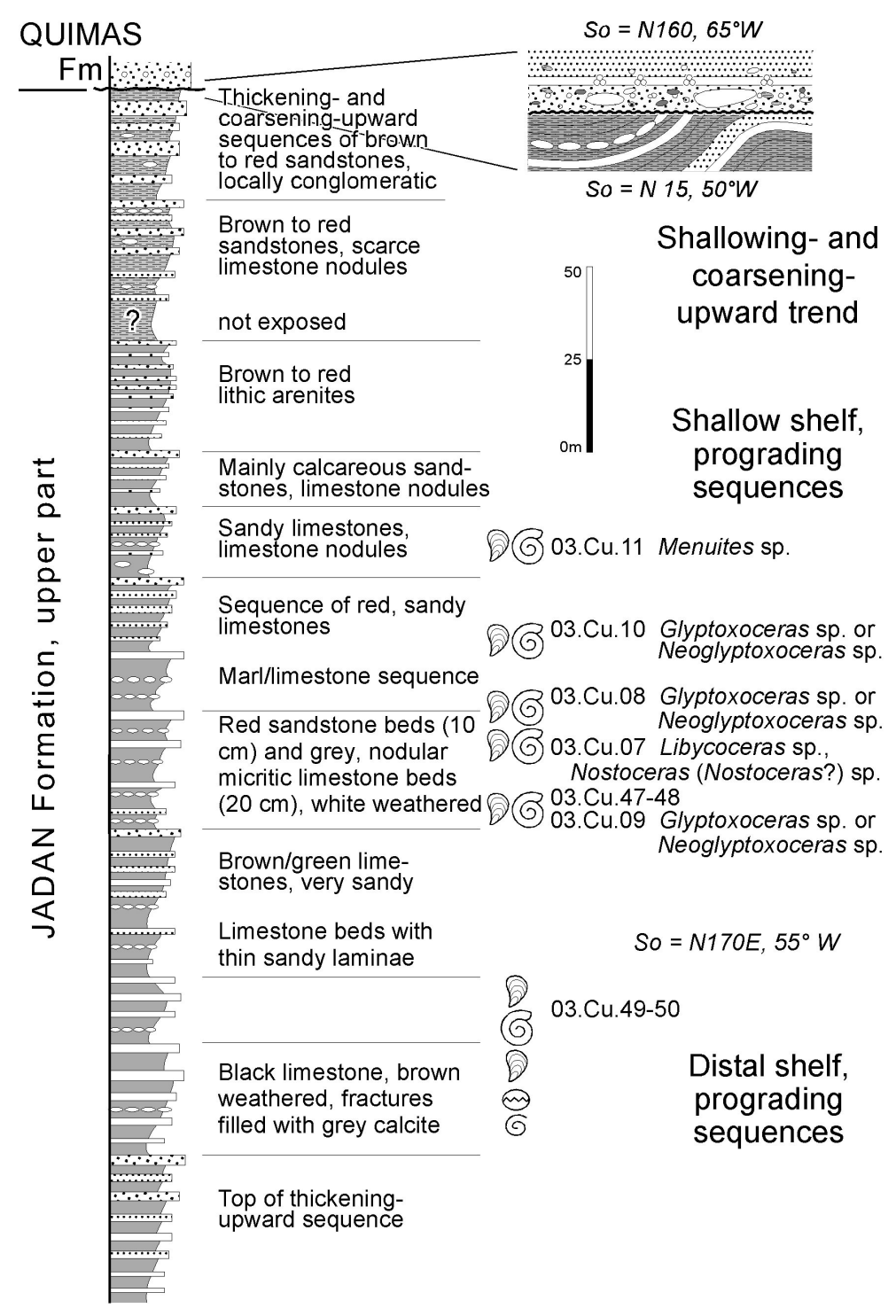

Fig. 4: Lithological succession of the upper Jadán Formation and contact with the Quimas Formation in Loma Tunasloma. Location on Figure 2.

- The middle part of the formation includes, in addition to the former lithologies, massive interbeds of black siliceous silts, thin-bedded calciturbidites, thin limestones interbedded with thin sandy laminae, and thick sandstone beds with coarsening-upward trends and progressive unconformities reflecting synsedimentary tectonic activity. The lower part of this unit yielded the Campanian ammonite Nostoceras (Nostoceras?) sp. (upper Campanian) ([03.Cu.03], Table 1).

- The upper part of the formation (Fig. 4) consists of shales, marls and limestones rich in ammonites, gastropods, oysters, inoceramids and other bivalves. This unit is composed of prograding, thickeningupwards sequences, of external, distal shelf environment, and is interpreted as representing a transgressive pulse. Toward the top, the limestones become progressively more sandy and eventually grade into conglomerates. We collected the ammonites Libycoceras sp. [03.Cu.07] (upper Campanian to lower or middle Maastrichtian), Nostoceras (Nostoceras?) sp. [03.Cu.07] (upper Campanian), Glyptoxoceras sp. (Santonian-Maastrichtian) or Neoglyptoxoceras sp. (lower-middle Campanian) [03.Cu.08, 09, 10] and Menuites sp. (Santonian-Maastrichtian) in Loma Tunasloma ([03.Cu.11], location in Table 1). In addition, a loose inoceramid found by D. Iza was identified as Cataceramus cf. pseudoregularis (Sornay, 1962), which is known from the uppermost Campanian of Tercis, France (lower part of the Nostoceras hyatti Zone, Walaszczyk et al., 2002). East of Azogues (Santa Bárbara), the upper part of the formation yielded Glyptoxoceras sp. (Santonian-Maastrichtian) or Neoglyptoxoceras sp. (lower-middle Campanian) [03.Cu.35, 03.Cu.36], and a pachydiscid, probably Menuites sp. [03.Cu.34] of Santonian to Maastrichtian age (Fig. 5). Thus, the weight of evidence suggests that the upper part of the Jadán Formation is upper 
Campanian.

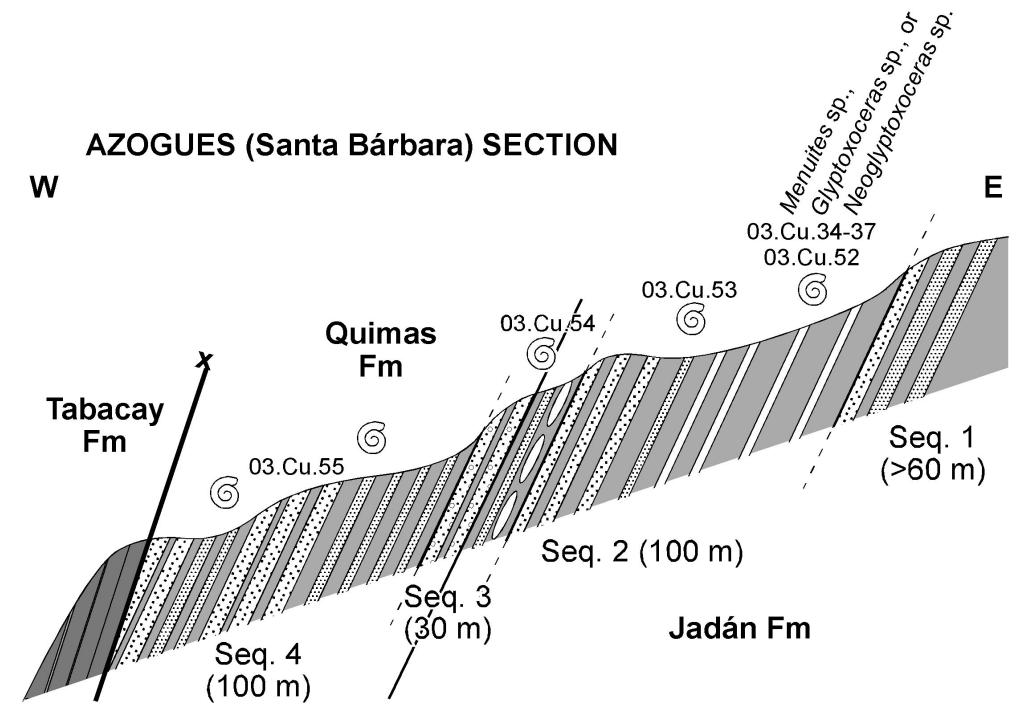

Fig. 5: Lithological succession of the upper Jadán to Tabacay formations, at Santa Bárbara (East of Azogues). Location on Figure 2.

Within their lithology 2, Faucher et al. (1971) identified, among others, the planktic foraminifers Globotruncana [= Gansserina] gr. gansseri Bolli, 1951, Plummerita hantkeninoides (Brönnimann, 1952), Rugoglobigerina macrocephala Brönnimann, 1952, R. cf. reicheli Brönnimann, 1952, R. gr. rugosa (Plummer, 1926), and the benthic foraminifers Rzehakina epigona var. lata Cushman \& Jarvis, 1929, Siphogenerinoides cf. bramlettei Cushman, 1929, S. cretacea Cushman, 1929, and S. reticulatus Stone, 1946 (det. J. Sigal). South of Santa Ana, in the Quebrada Salada, we collected Platyceramus sp., of late Coniacianearly Maastrichtian age, from undifferentiated Jadán Formation. Near Cumbe, shales and marls with limestone nodules and arkosic sandstone interbeds ascribed to the Jadán Formation yielded planktic and benthic foraminifers; the association of Bulimina midwayensis (Cushman \& Parker, 1936) (CampanianPaleocene), Haplophragmoides aff. horridus (Grzybowski, 1901) (Campanian-Paleogene), Hedbergella holmdelensis Olsson, 1964 (Late Cretaceous), Nodosaria cf. longiscata d'Orbigny, 1846 (MaastrichtianEocene), Praebulimina reussi (Morrow, 1934) (Late Cretaceous) and Turrilina carseyae (Plummer, 1931) (Campanian-Maastrichtian) indicates a Campanian-Maastrichtian age for these outcrops.

\section{Quimas Formation (uppermost Campanian-lowermost Maastrichtian)}

The Quimas Formation consists of thick beds of coarse to microconglomeratic arkosic and lithic sandstones, poorly sorted conglomerates, and subordinate lithic arenites and limestone nodules containing benthic foraminifers. The base of the Quimas Formation is defined at the base of the first erosional conglomerate bed. However, the lithologic change from the upper Jadán Formation to the lower Quimas Formation is progressive, and mainly expressed by the increase in conglomerates and erosional surfaces (Fig. 4 and 5). The Quimas Formation is best exposed along the Cumbe-Quingeo road, notably in the Quebrada Quimas and in Loma Huairapungu. This section is proposed as the type section. Other outcrops occur north of Santa Ana and east of the El Descanso-Azogues road.

The conglomerates contain subangular to well-rounded clasts up to $10 \mathrm{~cm}$ in size. The clasts consist dominantly of quartz, metamorphic and sedimentary rocks, and scarce volcanic rocks. The sandstones are commonly turbidite beds, which contain quartz (30-50\%), feldspar (20-35\%), lithic fragments (30-40\%) and scarce detrital micas. Steinmann (1997) reports a heavy mineral assemblage (34\% zircon, 21\% tourmaline, $20 \%$ apatite, $20 \%$ garnet, ...) typical of crystalline, plutonic and metamorphic source zones. In the Quebrada Tabacay, north of Azogues, conglomerates with well-rounded quartz and metamorphic clasts contain gastropods and bivalves. In Loma Tunasloma, marine bivalves, plant remains and bone fragments indicate a locally shallow-marine depositional environment. Fine-grained sediments show bioturbation, laminae and ripples, suggesting a shelf environment.

The formation contains numerous synsedimentary unconformities, folds and slumps, as well as debris flows, which indicate contemporaneous tectonic activity and/or a steep slope. Conglomerate beds are 
commonly lens-shaped and channelized, indicating the proximity of fluvial systems that fed fan deltas prograding on the shelf. The formation appears to reach a thickness of $1000 \mathrm{~m}$ in the Cumbe-Quingeo area, and grades northwards into much thinner (approximately $500 \mathrm{~m}$ ) and finer-grained deposits, near Azogues. This suggests that the feeding alluvial system (alluvial fan and fan delta) was located in the Cumbe area. As a whole, the Quimas Formation is interpreted as a fan delta deposit prograding on a steep shelf.

East of Antonio Borrero (Fig. 6), Bristow (in Bristow and Hoffstetter, 1977; and pers. comm., 2003) reported Sphenodiscus peruvianus Gerth, 1928 and Solenoceras sp. of early Maastrichtian age (determined by M.K. Howarth, Natural History Museum, London). In the same area (Fig. 6), we found ammonite fragments, which may be either Glyptoxoceras sp. (Santonian-Maastrichtian) or Neoglyptoxoceras sp. (lower-middle Campanian) ([02.C.G2, 03.Cu.38], Table 1). East of Azogues, the base of the formation yielded unidentifiable ammonites [03.Cu.54-55], which directly overlie the upper Campanian species mentioned above (Fig. 5). Based on the above evidences, the Quimas Formation is considered of latest Campanian to earliest Maastrichtian age.

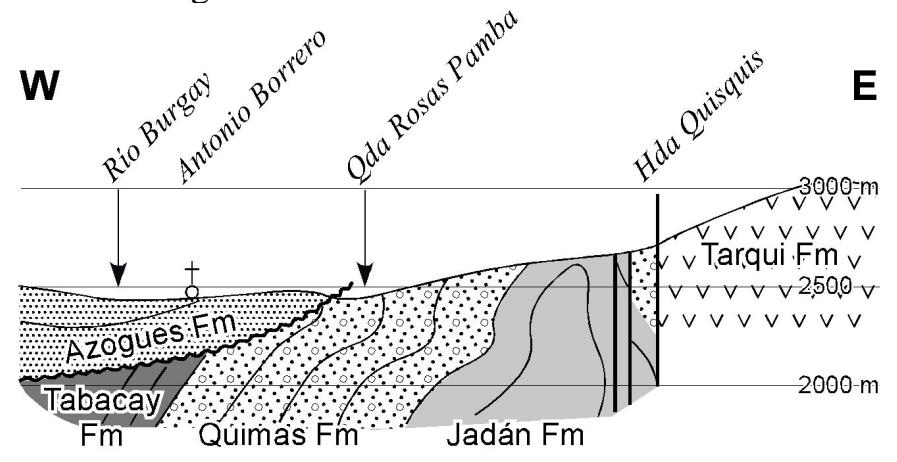

Fig. 6: Structural section of the Yunguilla Group East of Antonio Borrero. Location on Figure 2.

\section{Tabacay Formation (lower Maastrichtian)}

The Tabacay Formation corresponds to the lithologic unit 1 of Faucher et al. (1971). The base of the formation is not exposed, except to the east of Azogues (Santa Bárbara), where it is faulted (Fig. 5), and north of Azogues, where it unconformably overlies both the Quimas Formation and undated metamorphic rocks (Vaca, 2005). North of Santa Ana and in the Quebrada Tabacay, the formation seems to rest disconformably on the Quimas Formation. However, no suitable type section has been found so far. Although the stratigraphic contact is not visible, the Tabacay Formation seems to rest unconformably on the Quimas Formation, since dip orientations and deformation styles are slightly different.

The Tabacay Formation is made up of a succession of dark, laminated cherts, alternating with variably thick, fine-grained polygenetic conglomerates, volcanogenic greywackes and arkosic lithic arenites. The clasts dominantly consist of volcanic rocks, associated with arkoses, lithic arenites, and chert fragments, as well as locally abundant white quartz. Nodules or irregularly bedded intercalations of micritic black limestones are common, whereas scarce calciturbidites with volcanic or feldspathic fragments are locally observed. The detrital beds are interpreted as turbidites, on account of their erosional bases, presence of flat pebbles and upward fining bedding. The detrital components of the Tabacay Formation indicate a dominantly volcanic source area and a subordinate crystalline basement provenance. The detrital fragments were deposited in a dysaerobic pelagic environment, in which autochtonous, fine-grained, siliceous mud was laid down. Although outcrops are scarce, the thickness of the Tabacay Formation seems to reach a few hundred meters.

Faucher et al. (1971) recorded Maastrichtian foraminifers (buliminids, arenaceous, Robulus sp., Globigerinella sp.) and scarce indeterminable bivalves, inoceramids and ammonites, within their lithologic unit 1. In the Quebrada Tabacay, Bristow (1973) found a diplomoceratid ammonite. Further north, in the Pallatanga area near Huangupud, we collected Exiteloceras sp. of Campanian age (or Glyptoxoceras sp., Santonian-Maastrichtian?) and a Hypophylloceras (Neophylloceras) sp., of probably early Maastrichtian age, from a comparable lithology (Jaillard et al., 2005).

\section{Saquisilí Formation (Paleocene)}

In the Quebrada Tabacay, although the contact is not visible, the Tabacay Formation is geometrically overlain by grey to black shales, dark siltstones, sandstone layers, and thicker beds of dark, micaceous and 
arkosic sandstones. North of Tabacay, the basal contact is an unconformity (Vaca, 2005). Beds or nodules of micritic dark limestones, and thin bedded sandy turbidites are locally observed. The beds of fine-grained sandstone show ripples, lamination, hummocky cross stratifications and load structures; they contain plant remnants and Glossifungites or Skolithos burrows. These features suggest deposition in a clastic distal shelf environment, above the storm wave base. The thickness of this unit may reach 500 to $1000 \mathrm{~m}$.

The rocks referred to here as the Saquisilí Formation were formerly included in the "Yunguilla Formation". They have yielded, among others, the benthic foraminifers Bathysiphon gerochi Myatlyuk, 1966 (Paleocene), Bulimina midwayensis (Cushman \& Parker, 1936) (Campanian-Paleocene) and the palynomorph Tricolporopollenites? sp., indicating a Paleocene age. Due to a similar lithology with abundant detrital white micas, these beds are now referred to the Saquisilí Formation, which, in the type locality, has been dated as Early to Mid Paleocene (McCourt et al., 1998; Hughes et al., 1999). A sample from the water divide between Cuenca and Quingeo yielded the benthic foraminifers Dorothia cylindracea (Bermudez, 1963) (Paleocene-Early Eocene) and Haplophragmoides cf. eggeri (Cushman, 1926) (Paleogene), thus suggesting that the Saquisilí Formation also crops out east of Cuenca.

Further north, graded-bedded conglomerates are observed along the Azogues-Ingapirca road (Vaca, 2005). These coarser-grained deposits are correletable with the Gallo Rumi Member of the Pallatanga area, which is assigned to the Upper Paleocene (Jaillard et al., 2004).

Bristow and Hoffstetter (1977) assumed that the "Yunguilla Formation" of the Cumbe area progressively grades upward into Paleocene variegated, fine-grained subaerial deposits. In the same area, Pratt et al. (1997) assumed a progressive change from the marine "Yunguilla Formation" to Maastrichtian red beds, and then to the Eocene Quingeo Formation. However, the deformation of the Maastrichtian deposits includes tight folds, the axis of which varies from E-W to N-S, whereas the continental deposits ascribed to the Quingeo Formation only exhibit NNE-trending gentle folds. Therefore, it is probable that a major unconformity separates upper Maastrichtian-Paleocene fine-grained subaerial deposits from the coarser-grained, Eocene Quingeo Formation.

\section{Correlations with neighbouring areas}

\section{Celica-Lancones Basin (southwestern Ecuador) and Paita area (northwestern Peru)}

The unconformable, transgressive Campanian-Maastrichtian sequence in the Celica-Lancones Basin, appears to rest on the Albian volcanic arc in the east, on deformed Cretaceous sediments in the central part, and on Paleozoic basement or Albian transgressive limestones in the west (Olsson 1934, Kennerley, 1973; Morris and Alemán, 1975; Jaillard et al., 2005). The uppermost Cretaceous sequence comprises, from base to top (Fig. 7): (1) a middle to upper Campanian prograding sequence of marls, limestones and arkosic sandstones, overlain by transgressive marls (Naranjo and Zapotillo formations); (2) coarse-grained conglomerates derived from either a volcanic source in the east (Casanga Formation) or a crystalline source in the west (Monte Grande, or Tablones Formation); and (3) lower Maastrichtian dark shales interbedded with quartzose sandstones (Cazaderos Formation) (Jaillard et al., 1996, 1999). The latter are unconformably overlain by Paleocene marine shales, with sandstone and limestone interbeds (Balcones Formation) (Jaillard et al., 1999).

In the Paita area (northwestern Peru, Fig. 1, 7), the Paleozoic basement is unconformably overlain by a middle-upper Campanian sequence of transgressive marine marls and sandy limestones, which ends with shallowing-upward, rudist-bearing carbonate shelf deposits (La Mesa Formation) (Olsson, 1944; Palacios, 1994; Jaillard et al., 1998). The latter formation is overlain by upper Campanian transgressive sandy marls, which rapidly grade upwards into quartz-rich conglomerates. Further to the west, the Paleozoic basement is directly overlain by a $3500 \mathrm{~m}$ thick upper Campanian-lower Maastrichtian succession of fan delta breccias (La Tortuga Formation) (Jaillard et al., 1998; Taipe et al., 2004), thus indicating that a deep sedimentary basin was created between the late Campanian and the early Maastrichtian. These breccias are disconformably overlain by lower Maastrichtian transgressive shoreline sandstones, which grade into shallow clastic shelf breccias and sandstones (Cenizo Formation). Paleocene marine marls unconformably overlie the Maastrichtian sandstones (Taipe et al., 2004; Jaillard et al., 2005).

The upper Campanian marls, limestones and arkoses of the Jadán Formation in the Cuenca area are lithologically comparable and stratigraphically correlatable with the transgressive Naranjo, Zapotillo and La Mesa formations of southwestern Ecuador and northwestern Peru. The conglomerates of the Quimas Formation are stratigraphically correlatable with those of the Casanga and Monte Grande (or Tablones) formations of the Celica-Lancones area and with the La Tortuga breccias of the Paita area. Although their 
source areas and depositional environments were different, the lower Maastrichtian cherts and volcanogenic turbidites of the Tabacay Formation can be correlated with the quartz-rich Cazaderos Formation of southwestern Ecuador and with the transgressive Cenizo Formation of northwestern Peru (Jaillard et al., 2005).

It follows that the sedimentary successions of the Paita, Celica-Lancones and Cuenca areas represent a three-fold evolution: (1) a mid to late Campanian transgressive prograding sequence, followed by a renewed transgression; (2) a significant tectonic event, with deposition of thick, shallow-marine to continental, coarse-grained conglomerates or breccias in the latest Campanian-earliest Maastrichtian; and (3) a new transgression and clastic-shelf or deeper turbiditic deposition in the early Maastrichtian. The latter sequence closes with a regional hiatus in the late Maastrichtian-earliest Paleocene, which reflects a significant tectonic event.

\section{Western Cordillera of central and northern Ecuador}

In central Ecuador $\left(0-2^{\circ} S\right)$ the Yunguilla Group is tectonically associated with basalts, dolerites and greywackes, which are interpreted as an accreted oceanic terrane (part of the Pallatanga terrane of McCourt et al., 1998; Kerr et al., 2002; Spikings et al., 2005; San Juan terrane of Mamberti et al., 2004; Jaillard et al., 2004). To the west, the late Campanian-Maastrichtian interval is represented by radiolarian-rich black cherts, which overlie red or green radiolarites (Fig. 7). In northern Ecuador, the radiolarian-bearing red mudstones were dated as Santonian-early Campanian (Boland et al., 2000; Kerr et al., 2002) and constitute the sedimentary cover of basalts, ankaramites and picrites, representing an accreted oceanic terrane (part of the Pallatanga terrane of McCourt et al., 1998; Kerr et al., 2002; Guaranda terrane of Mamberti et al., 2003; Jaillard et al., 2004). Thus, the Yunguilla Group was deposited only on the eastern San Juan oceanic unit.

The Yunguilla sediments of central Ecuador are highly deformed, and it is difficult to ascribe them to any of the formations defined in the Cuenca area. However, their quartz content is low ( $\leq 20 \%$, Toro and Jaillard, 2005), available paleontological data suggest an early Maastrichtian age (Jaillard et al., 2005), and there are no quartz-rich conglomerates similar to the Quimas Formation. For these reasons, the Yunguilla sediments of the Quito-Pallatanga area are tentatively referred to the Tabacay Formation (lower Maastrichtian). If this is correct, the Tabacay Formation postdates the accretion of the eastern San Juan oceanic terrane (Hughes and Pilatasig, 2002; Kerr et al., 2002) and predates the accretion of the western Guaranda oceanic terrane (Jaillard et al., 2004). Therefore, the deposition of the coarse-grained conglomerates of latest Campanianearliest Maastrichtian age $(\approx 75-70 \mathrm{Ma})$ are interpreted as the sedimentary response to the accretion of the San Juan oceanic terrane.

The Paleocene Saquisilí Formation in the Cuenca area exhibits similar lithologies and is coeval with that in central and northern Ecuador. In the latter area, it unconformably overlies both the Maastrichtian Tabacay Formation (San Juan Terrane), and the Campanian-Maastrichtian black cherts (Guaranda Terrane), thus concealing the accretion of the latter terrane to the former (Jaillard et al., 2004). Therefore, the accretion of the Guaranda terrane occurred in the late Maastrichtian-earliest Paleocene ( $\approx 68-65 \mathrm{Ma}$; Fig. 7).

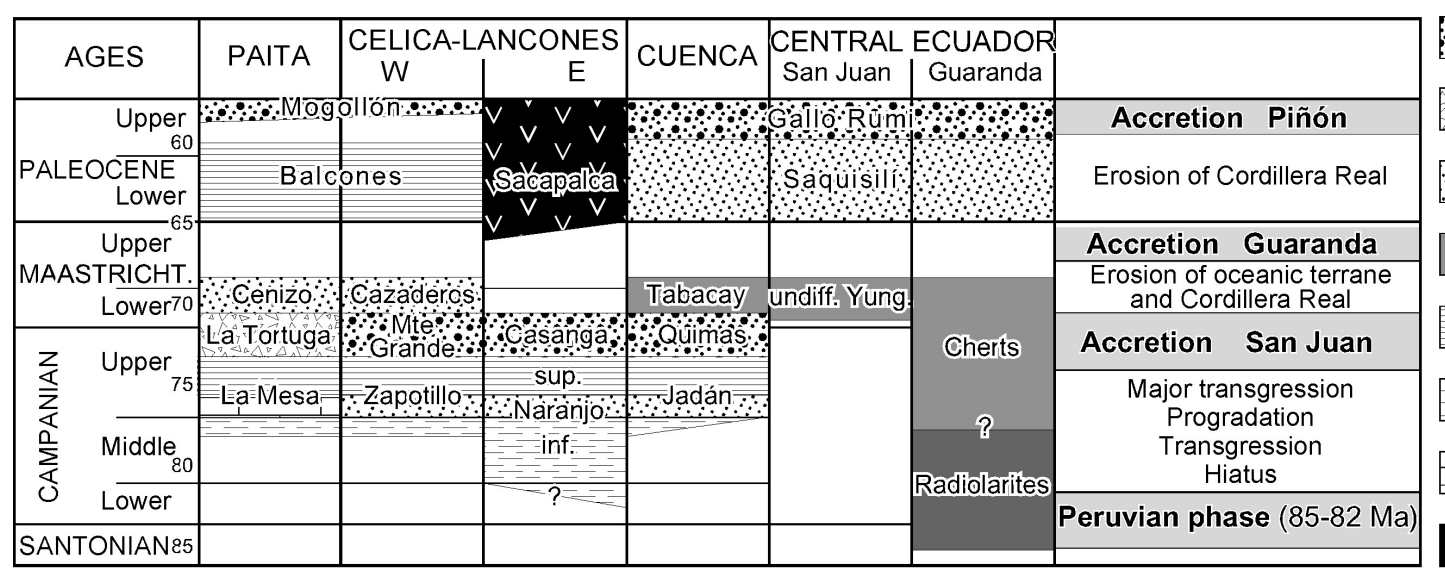

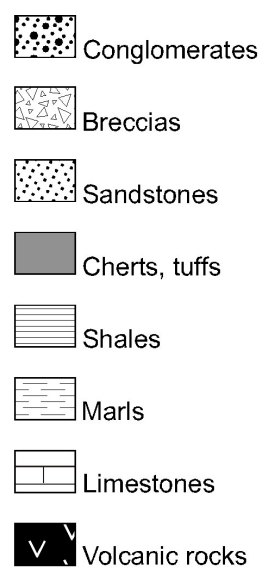

Fig. 7: Correlations between the upper Cretaceous-Paleocene series of the Cuenca area and other parts of Ecuador and northernmost Peru, and interpretation of tectonic events. 


\section{Oriente Basin of Ecuador}

The Cretaceous, fine-grained, shallow-marine sediments in the Oriente Basin (Napo Group) record the arrival of significant detrital input in the Santonian, which predates a major hiatus of late Santonian to early Campanian times (Jaillard, 1997; Jaillard et al., 2005). These deposits are disconformably overlain by a 5 to 20-m-thick middle to upper Campanian transgressive sequence of sandstones and thin marine shales (M-1 Sandstones, Raynaud et al., 1993; Rivadeneira et al., 1995). However, in the western part of the Oriente Basin and in the Subandean Zone, Campanian sediments are absent. There, lower Maastrichtian sandstones unconformably overlie the eroded marine shales and limestones, which are dated as Turonian to Santonian, depending on the region (Faucher et al., 1971; Jaillard, 1997). Therefore, in the western part of the Oriente Basin a late Campanian hiatus coincides with the accretion of the eastern San Juan terrane (Hughes and Pilatasig, 2002; Jaillard et al., 2004).

The early Maastrichtian transgression (Basal Tena Formation) is overlain by prograding, fine-grained red beds (Lower Tena Formation) (Faucher et al., 1971; Jaillard, 1997; Ruiz et al., 2004). These are, in turn, disconformably overlain by a succession of Paleocene coarser-grained fluvial red beds (Mills, 1972; Jaillard, 1997). Thus, a hiatus occurred some time after the early Maastrichtian and before part of the Paleocene, coinciding with the accretion of the western Guaranda unit (Mamberti et al., 2003; Jaillard et al., 2004).

It should be noted that the Paleocene Upper Tena Formation is in turn eroded and unconformably overlain by coarse-grained fluvial conglomerates of the poorly dated Lower Tiyuyacu Formation (Christophoul et al., 2002). Although poorly constrained, this major unconformity would correlate with the accretion of the Piñón Terrane of southern coastal Ecuador in the Late Paleocene ( $\approx 58-55$ Ma; Jaillard et al., 1995). These observations demonstrate that the accretion of oceanic terranes coincides with important sedimentary hiatuses in the Subandean Zone and Oriente Basin and therefore, with uplift and erosion of those areas.

\section{Geodynamic interpretations and discussions}

The middle to late Campanian Jadán Formation represents the oldest Cretaceous sediments exposed in the Cuenca area. Although the stratigraphic contact is not visible, we assume that it was unconformably deposited onto the metamorphic basement of the Andean margin. A similar unconformable contact of transgressive mid to late Campanian resting on deformed, Albian to Paleozoic rocks of the Andean margin is known from the forearc zones of southwestern Ecuador and northwestern Peru (Jaillard et al., 1996; 1998; 1999 ; Taipe et al., 2004). This suggests that a strong subsidence affected the western edge of the Andean continental margin of southern Ecuador by mid Campanian times. Since this subsidence event followed the compressional «Peruvian phase », we suggest that the latter was responsible for a strong tectonic erosion of the forearc continental edge, which accounts for the subsequent subsidence of the forearc zones (Jaillard and Soler, 1996).

The Cuenca succession exhibits four distinct lithological units, which reflect distinct paleogeographic settings and geodynamic events (Fig. 7).

The Jadán and Quimas formations are separated by a significant, though progressive coarsening of the detrital input, evidencing a significant rejuvenation of the eastern reliefs in the late Campanian. Therefore, the accretion of the San Juan terrane provoked the incipient uplift and erosion of the Eastern Cordillera and the ongoing coarse, quartz-rich detrital input (Quimas conglomerates). The significant change from a crystalline source area in the Jadán and Quimas formations to a mainly volcanic source area in the Tabacay Formation reflects the onset of erosion of the newly accreted San Juan oceanic terrane. The abundance of feldspars suggests that erosion mainly affected volcanic arc rocks. However, in southwestern Ecuador (Cazaderos Formation), the volcanic clastic input is less significant.

Accretion of oceanic terranes and related uplift and erosion of the Andean continental margin is classically admitted to have begun in the Campanian (e.g. Lebrat et al., 1987; Daly, 1989; Reynaud et al., 1999; Kerr et al., 2002 ; Hughes and Pilatasig, 2002; Jaillard et al., 2004; Toro and Jaillard, 2005; Vallejo et al., 2006; Luzieux et al., 2006). Based on thermochronological studies, Spikings et al. $(2001 ; 2005)$ proposed that (1) uplift of the Andean continental margin is older in southernmost Ecuador (75-65 Ma) than in the rest of the country (65-60 Ma), although Late Cretaceous $(\approx 75 \mathrm{Ma}$ ) cooling of continental basement is recorded by Paleocene sediments in central Ecuador (Spikings et al., 2005), and (2) uplift of the Andean margin began earlier to the West than to the East. On the other hand, the Eastern Cordillera became a source area for deposits of the Oriente basin by early Maastrichtian times ( $\approx 0$ Ma; Baldock, 1982; Jaillard, 1997; Ruiz et 
al., 2004). These dates are consistent with the latest Campanian age (75-70 Ma). for the accretion of the San Juan terrane, inferred from the sedimentary record in the Cuenca area.

The Tabacay and Saquisilí formations differ from each other by quite distinct clastic sources, different deformation styles, and are separated by a probable unconformity, interpreted as the result of the accretion of the Guaranda terrane, during the late Maastrichtian (to earliest Paleocene ?; 68-65 Ma). The change from a mainly volcanic source in the Maastrichtian to a crystalline source in the Paleocene would reflect the renewed uplift and erosion of the Eastern Cordillera, related to the Guaranda terrane accretion. This interpretation is in agreement with recent studies (Spikings et al., 2001; 2005; Jaillard et al., 2005; Vallejo et al., 2006).

Most accretionary events of oceanic terranes resulted in the uplift and erosion of the Eastern Cordillera. Moreover, accretions of oceanic terranes in western Ecuador (late Campanian, late Maastrichtian, late Paleocene) correlate with significant sedimentary hiatuses in the Subandean Zone and locally in the Oriente Basin (Upper Napo/Lower Tena, Lower/Upper Tena, and Upper Tena/Lower Tiyuyacu unconformities). These observations demonstrate that accretions of oceanic terranes provoked the uplift of the Andean continental margin, this uplift being higher toward the west (Fig. 8). The Oriente Basin of Ecuador, therefore, cannot be considered as a flexural foreland basin at that time. Conversely, deposits in the forearc zone are thick and localised, due to structural sediment traps related to the deformation of both the Andean margin and the oceanic terranes. We propose that accretion of oceanic terranes through subduction jam added relatively buoyant oceanic material beneath the western edge of the continental margin, thus provoking its westward increasing uplift. In this view, accretion and tectonic underplating of oceanic material beneath the continental margin would be a major process in the creation of relief and crustal thickening of the early Andes of Ecuador (Fig. 8).

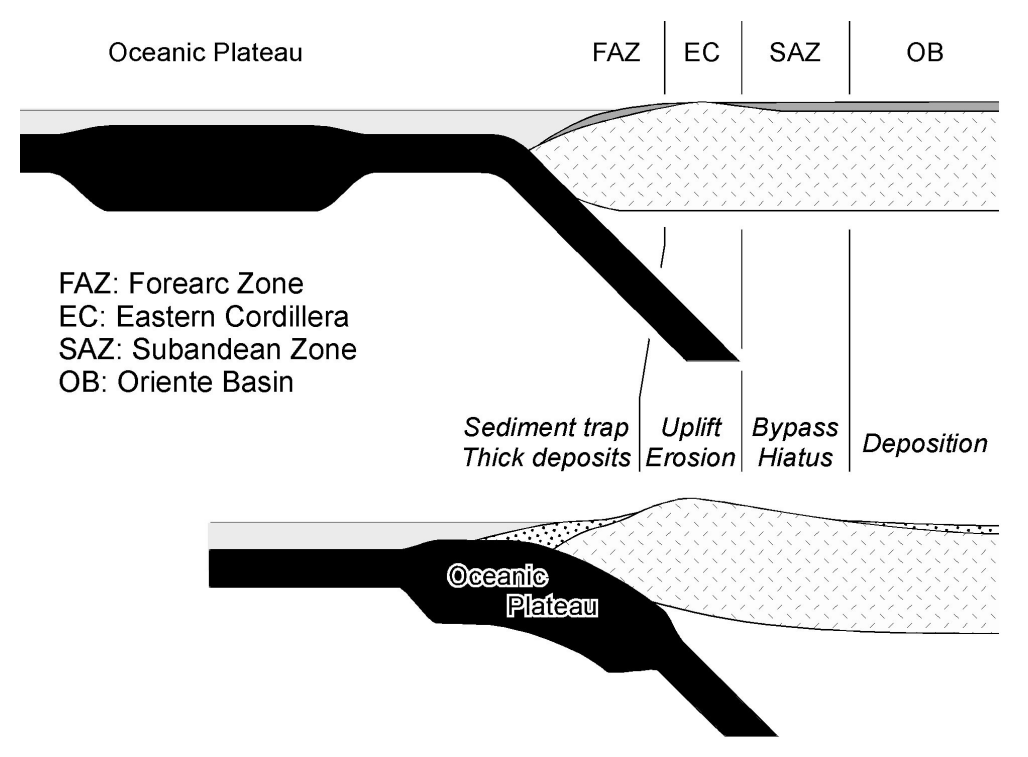

Fig. 8: Interpreted consequences of terrane accretion on syntectonic sedimentation on the Ecuadorian margin.

Addition of buoyant material beneath the continental margin provokes the uplift of the western part of the margin, and hiatuses in the Subandean Zone, whereas the deformation of the continental margin and oceanic terrane creates sediment traps in the forearc zone.

\section{Conclusions}

The uppermost Cretaceous unconformable clastic deposits of the Cuenca area, here referred to as the Yunguilla Group, include from base to top, distal shelf fine-grained marls, arkoses and limestones (Jadán Formation, middle and upper Campanian); coarse-grained, quartz-rich shelf and fan delta conglomerates (Quimas Formation, uppermost Campanian-lowermost Maastrichtian), and unconformable black cherts interbedded with volcanogenic turbidites (Tabacay Formation, lower Maastrichtian). This succession resembles that of the Paita and Celica-Lancones regions, indicating that the Campanian-Maastrichtian basin extended to the south as far as northern Peru. The creation of such a mid Campanian forearc basin evidences a strong subsidence, interpreted as due to a significant tectonic erosion, resulting from the former compressional Peruvian phase (late Santonian-early Campanian). The Yunguilla Group is overlain, probably 
unconformably, by quartz-rich, micaceous distal shelf sandstones (Saquisilí Formation, Paleocene).

The conglomerates of the Quimas Formation are interpreted as reflecting the accretion of the San Juan oceanic terrane (eastern part of Pallatanga terrane), whereas the Maastrichtian-Paleocene boundary unconformity is interpreted as the result of the accretion of the Guaranda oceanic terrane (western part of Pallatanga terrane). These accretionary events correlate with a rejuvenated erosion of the Eastern Cordillera, and with uplifts and erosional hiatuses in the Subandean Zone and Oriente Basin of Ecuador, indicating that accretion and tectonic underplating of oceanic material beneath the continental margin induced the jerky uplift of a large western part of the continental margin. Therefore, the Oriente Basin of Ecuador cannot be considered as a flexural foreland basin at that time.

Acknowledgements. This work was carried out in the frame of a scientific agreement between Petroproducción (filial of Petroecuador) and the Institut de Recherche pour le Développement-IRD. The IRD (UR 154) supported field work and sample expeditions. We are grateful to G. Gastineau, D. Iza and W. Lugo for their participation to field work and fossil findings, to R. Bristow and W. Pratt for fruitful discussions and correspondences, and to R. Campaña and M. Rivadeneira for their constant support of this scientific agreement. R. Spikings and an anonymous referee are thanked for their constructive reviews.

\section{References cited}

Arculus, R.J., Lapierre, H., Jaillard, É., 1999. A geochemical window into subduction-accretion processes: the Raspas Metamorphic Complex, Ecuador. Geology, 27, 547-550.

Baldock, J.W., 1982. Geología del Ecuador. Boletín de Explicación del Mapa geológico de la República del Ecuador. Dirección General de Geología y Minas, Quito, 70 p.

Bermúdez, P.J., 1963. Foraminíferos de las lutitas de Punta Tolete, Territorio Delta Amacuro, Venezuela, p.765-768 en : Micropaleontologia general, Univ. Central Venez., 808 p.

Boland, M.P., McCourt, W.J., Beate, B., 2000. Mapa geológico de la Cordillera Occidental del Ecuador entre $0^{\circ}-1^{\circ} \mathrm{N}$, escala 1/200.000. Ministerio de Energía y Minas-BGS publs., Quito.

Bolli, H.M., 1951. The genus Globotruncana in Trinidad, BWI. Journal of Paleontology, 25, 187-199.

Bristow, C.R., 1973. Guide to the geology of the Cuenca Basin, southern Ecuador. Ecuadorian Geological and Geophysical Society, Quito, 45 pp.

Bristow, C.R., 1980. Mapa geológico al 1/100.000, hoja Azogues. Ministerio de Recursos Naturales y Energía, Dirección de Geología y Minas, Quito.

Bristow, C.R., Hoffstetter, R., 1977. Ecuador. Lexique Stratigraphique International, V, 5a2, 410 p., CNRS publ., Paris.

Brönimann, P., 1952. Globigerinidae from the Upper Cretaceous (Cenomanian-Maastrichtian) of Trinidad, BWI. Bulletin of American Paleontology, 34, 5-71.

Christophoul, F., Baby, P., Rivadeneira, M., Dávila, C., 2002. Stratigraphic responses to a major tectonic event in a foreland basin: the Ecuadorian Oriente Basin from Eocene to Oligocene times. Tectonophysics, 345, 281-298.

Cushman, J.A., 1929. Some species of Siphogenerinoides from the Cretaceous of Venezuela. Contribution Cushman Laboratory Foraminifer Research, 5, 55-59.

Cushman, J.A., Jarwis, P.W., 1929. Cretaceous Foraminifera from Trinidad. Contribution Cushman Laboratory Foraminifer Research, 4, 85-103.

Cushman, J.A., Parker, F.L., 1936. Notes on some Cretaceous species of Buliminella and Neobulimina. Contribution Cushman Laboratory Foraminifer Research, 12, p. 510.

Daly, M.C., 1989. Correlations between Nazca/Farallón plate kinematics and Forearc basin evolution in Ecuador. Tectonics, 8, 769-790.

Dunkley, P.N., Gaibor, A., 1998. Mapa geológico de la Cordillera Occidental del Ecuador entre $2^{\circ}-3^{\circ}$ S., escala 1/200.000. CODIGEM-Ministerio de Energía y Minas-British Geological Survey publs., Quito.

Egüez, A., Bourgois, J., 1986. La formación Apagua: edad y posición estructural en la Cordillera occidental del Ecuador. Actas IV Congreso Ecuatoriano de Ingeniería, Geología, Minería y Petroleo, t. I, 161-178, Quito.

Faucher, B., Vernet, R., Bizon, G., Bizon, J.J., Grekoff, N., Lys, M., Sigal, J., 1971. Sedimentary formations in Ecuador. A stratigraphic and micropaleontological survey. Bureau d'Études Industrielles et Coopération de l'Institut Français du Pétrole (BEICIP), 220 pp., 3 vol..

Feininger, T., Bristow, C.R., 1980. Cretaceous and Paleogene history of coastal Ecuador: Geologische Rundschau, 69, $849-874$

Gansser, A., 1973. Facts and Theories on the Andes. Journal of the Geological Society, London, 129, 93-131.

Gerth, H., 1928. Neue Faunen der oberen Kreide mit Hippuriten aus Nordperu, Leidsche geologische Mededeel, 2, 232241.

Goossens, P.J., Rose, W.I., 1973. Chemical composition and age determination of tholeitic rocks in the basic Cretaceous Complex, Ecuador. Geological Society of America Bulletin, 84, 1043-1052.

Grzybowski, J., 1901. Die Microfauna der Karpathenbildungen; III - Die Foraminiferen der Inoceramenschichten von 
Gorlice. Académie des Sciences de Cracobie, Sci. Mathématiques et Naturelles, Bulletin International, 4, $221-226$.

Guillier, B., Chatelain, J.-L., Jaillard, É., Yepes, H., Poupinet, G., Fels, J.-F., 2001. Seismological evidence on the geometry of the orogenic system in Central-Northern Ecuador (South America). Geophysical Research Letters, 28, 3749-3752.

Henderson, W.G., 1981. The volcanic Macuchi Formation, Andes of Northern Ecuador. Newsletters on Stratigraphy, 9 , 157-168, Stuttgart.

Hughes, R.A., Bermúdez, R., Espinel, G., 1999. Mapa geológico de la Cordillera Occidental del Ecuador entre $0^{\circ}-1^{\circ} \mathrm{S}$, escala 1:200.000. CODIGEM-Minist. Energ. Minas-BGS publs., Quito.

Hughes, R.A., Pilatasig, L.F., 2002. Cretaceous and Tertiary terrane accretion in the Cordillera Occidental of the Andes of Ecuador. Tectonophysics, 345, 29-48.

Hungerbühler, D., Steinmann, M., Winkler, W., Seward, D., Egüez, A., Peterson, D.E., Elg, U., Hammer, C., 2002. Neogene stratigraphy and Andean geodynamics of southern Ecuador. Earth Science Reviews, 57, 75-124.

Jaillard, É., 1997. Síntesis estratigráfica y sedimentológica del Cretáceo y Paleógeno de la cuenca oriental del Ecuador. 164 p., Orstom-Petroproducción publ., Quito.

Jaillard, E., Ordoñez, M., Benítez, S., Berrones, G., Jiménez, N., Montenegro, G., Zambrano, I., 1995. Basin development in an accretionary, oceanic-floored forearc setting : southern coastal Ecuador during late Cretaceous to late Eocene times. In: Petroleum Basins of South America, A.J. Tankard, R. Suárez, H.J. Welsink, eds., American Association of Petroleum Geologists Memoir, 62, 615-631.

Jaillard, É., Ordoñez, M., Bengtson, P., Berrones, G., Bonhomme, M., Jiménez, N., Zambrano, I., 1996. Sedimentary and tectonic evolution of the arc zone of southwestern Ecuador during Late Cretaceous and Early Tertiary times. Journal of South American Earth Sciences, 9, 131-140.

Jaillard, E., Soler, P., 1996. The Cretaceous to Early Paleogene tectonic evolution of the northern Central Andes and its relations to geodynamics. Tectonophysics, 259, 41-53.

Jaillard, É., Laubacher, G., Bengtson, P., Dhondt, A., Philip, J., Bulot, L.G., Robert, E., 1998. Revisión estratigráfica del Cretáceo superior del Noroeste peruano y Suroeste ecuatoriano. Datos preliminares y consecuencias tectónicas. Boletin de la Sociedad geológica del Perú, 88, 101-115, Lima.

Jaillard, É., Laubacher, G., Bengtson, P., Dhondt, A., Bulot, L., 1999. Stratigraphy and evolution of the Cretaceous forearc "Celica-Lancones Basin" of Southwestern Ecuador. Journal of South American Earth Sciences, 12, 51-68.

Jaillard, E., Hérail, G., Monfret, T., Wörner, G., 2002. Andean geodynamics: main issues and contributions from the 4th ISAG, Göttingen. Tectonophysics, 242, 1-15.

Jaillard, E., Ordoñez, O., Suárez, J., Toro, J., Iza, D., Lugo, W., 2004. Stratigraphy of the Late Cretaceous-Paleogene deposits of the Western Cordillera of Central Ecuador : Geodynamic implications. Journal of South American Earth Sciences, 17, 49-58.

Jaillard, É., Bengtson, P., Dhondt, A., 2005. Late Cretaceous marine transgressions in Ecuador and northern Peru: a refined stratigraphic framework. Journal of South American Earth Sciences, 19, 307-323.

Kehrer, W., Kehrer, P., 1969. Die oberkretazische San Juan Formation der Westkordillere Ecuadors. Neue Jahrbuch für Geologie und Paläontologie. Abhandlungen, 133, 1-22, Stuttgart.

Kennerley, J.B., 1973. Geology of the Loja Province, Southern Ecuador. London Institute of Geological Sciences, Report 23, 34 p., London.

Kerr, A.C., Aspden, J.A., Tarney, J., Pilatasig, L.F., 2002. The nature and provenance of accreted terranes in Western Ecuador: Geochemical and tectonic constraints. Journal of the Geological Society, London, 159, 577-594.

Lavenu, A., Baudino, R., Égo, F., 1996. Stratigraphie des dépôts tertiaires et quaternaires de la dépression interandine d'Équateur (entre $0^{\circ}$ et $2^{\circ} 15^{\prime} \mathrm{S}$ ). Bulletin de l'Institut Français d'Études Andines, 25, 1-15, Lima.

Lebrat, M., Mégard, F., Dupuy, C., Dostal, J., 1987. Geochemistry and tectonic setting of pre-collision Cretaceous and Paleogene volcanic rocks of Ecuador. Geological Society of America Bulletin, 99: 569-578.

Litherland, M., Aspden, J.A., Jemielita, R.A., 1994. The metamorphic belts of Ecuador. British Geological Survey, Overseas Memoir 11, 147 pp., 2 maps, Keyworth, UK.

Luzieux, L., Heller, F., Spikings, R., Vallejo, C., Winkler, W. (2006). Origin and Cretaceous history of the coastal Ecuadorian forearc between $1^{\circ} \mathrm{N}$ and $3^{\circ} \mathrm{S}$ : paleomagnetic, radiometric and fossil evidence. Earth and Planetary Science Letters, 249, 400-414.

Mamberti, M., Lapierre, H., Bosch, D., Ethien, R., Jaillard, É., Hernandez, J., Polvé, M., 2003. Accreted fragments of the Late Cretaceous Caribbean-Colombian Plateau in Ecuador. Lithos, 66, 173-199.

Mamberti, M., Lapierre, H., Bosch, D., Jaillard, É., Hernandez, J., Polvé, M., 2004. The Early Cretaceous San Juan plutonic suite, Ecuador: a magma chamber in an Oceanic Plateau. Canadian Journal of Earth Sciences, 41, 12371258.

McCourt, W.J., Duque, P., Pilatasig, L.F., Villagómez, R., 1998. Mapa geológico de la Cordillera Occidental del Ecuador entre $1^{\circ}-2^{\circ}$ S., escala 1/200.000. CODIGEM-Ministerio Energía y Minas-BGS publs., Quito.

Mills, S.J., 1972. A review of micropaleontological evidence from the Ecuadorian Oriente. Anglo-Ecuadorian Oilfields Ltd, Ecuadorian Oriente Geological note n²6, 21 pp., Petroproducción-Quito.

Morris, R.C., Alemán, A.R., 1975. Sedimentation and tectonics of middle Cretaceous Copa Sombrero formation in northwest Peru. Boletín de la Sociedad geológica del Perú, 48, 49-64, Lima.

Morrow, A.L., 1934. Foraminifera and Ostracoda from the Upper Crretaceous of Kansas. Journal of Paleontology, 8, 186-205. 
Myatlyuk, E.V., 1966. O foraminiferakh s kremnevym skeletom. Voprosy Mikropaleontologii, 10, 255-269.

Noblet, C., Lavenu, A., Schneider, F., 1988. Étude géodynamique d'un bassin intramontagneux tertiaire sur décrochements dans les Andes du Sud de l'Équateur: l'exemple du bassin de Cuenca. Géodynamique, 3, 117-138, IRD Publ., Paris.

Olsson, A.A., 1934. Contributions to the Paleontology of northern Peru. The Cretaceous of the Amotape region. Bulletins of American Paleontology, 20, 104 p., New-York.

Olsson, A.A., 1944. Contributions to the Paleontology of Northern Peru. Part VII: The Cretaceous of the Paita region. Bulletins of American Paleontology, 28, 113 pp., New-York.

Olsson, R.K., 1964. Late Cretaceous planktonic foraminifera from New jersey and Delaware. Micropaleontology, 10, 157-188.

Palacios, O., 1994. Geología de los cuadrángulos de Paita, Talara, Sullana, Lobitos, Quebrada Seca, Zorritos, Tumbes y Zarumilla. Boletín INGEMMET, (A), 54, 190 pp., 1 pl. h.t., Lima.

Plummer, H.J., 1926. Foraminifers of the Midway Formation in Texas. Texas University Bulletin, 2644, 1-206.

Plummer, H.J., 1931. Some Cretaceous foraminifera in Texas. Bulletin of the University of Texas, Bur. Econ. Geol. Technol., 3101, 109-203.

Pratt, W.T., Figueroa, J.F., Flores, B.G., 1997. Geology of the Cordillera Occidental of Ecuador between $3^{\circ} 00^{\prime}$ and $4^{\circ} 00^{\prime}$ S. World Bank Mining Development and environmental Control Project, Report $\mathrm{n}^{\circ}$ 1, 58 pp., CODIGEMBritish Geological Survey, Quito.

Pratt, W.T., Figueroa, J.F., Flores, B.G., 1998. Mapa geológico de la Cordillera Occidental del Ecuador entre $3^{\circ}-4^{\circ} \mathrm{S}$, escala 1/200.000. CODIGEM-Ministerio de Energía y Minas-BGS publs., Quito.

Raynaud, J.-F., Bouroullec, J., Homewood, P., Villanova, M., 1993. Equateur, Bassin de l'Oriente : Etude palynologique d'un intervalle Crétacé supérieur sur 20 puits. Etude sédimentologique des grès M-1. Elf-Aquitaine Production proprietary Report, 98 pp., 19 plates.

Reynaud, C., Jaillard, É., Lapierre, H., Mamberti, M., Mascle, G.H., 1999. Oceanic plateau and island arcs of southwestern Ecuador: their place in the geodynamic evolution of northwestern South America. Tectonophysics, 307, 235-254.

Rivadeneira, M., Dávila, C., Toro, J., 1995. La Arenisca «M-1» en la cuenca ecuatoriana. Congreso Petroleo y Medio ambiente, Quito, Nov. 95, 15 pp., 9 fig.

Ruiz, G., Seward, D., Winkler, W., 2004. Detrital thermochronology - a new perspective on hinterland tectonics, an example from the Andean Amazon Basin, Ecuador. Basin Research, 16, 413-430.

Steinmann, M., 1997. The Cuenca Basin of southern Ecuador: tectono-sedimentary history and the Tertiary Andean evolution. PhD thesis, ETH Zürich, ${ }^{\circ} 12297,176$ pp.

Santos, M., Ramírez, F., 1986. La Formación Apagua, una nueva unidad eocénica en la cordillera occidental ecuatoriana. Actas IV Congreso Ecuatoriano de Ingeniería, Geología, Mineralogía y Petróleo, tomo I, 179-190, Quito.

Sigal, J., 1969. Quelques acquisitions récentes concernant la chronostratigraphie des formations sédimentaires de l'Équateur. Revista Española de Micropaleontología, 1, 205-236,

Sornay, J., 1962. Etude d'une faune d'inocérames du Sénonien supérieur des Charentes et description d'un espèce nouvelle du Sénonien supérieur de Madagascar. Bulletin de la Société géologique de France, 7, 118-122.

Spikings, R.A., Winkler, W., Seward, D., Handler, R., 2001. Along-strike variations in the thermal and tectonic response of the continental Ecuadorian Andes to the collision with heterogeneous oceanic crust. Earth and Planetary Science Letters, 186, 57-73.

Spikings, R., Winkler, W., Hughes, R.A., Handler, R., 2005. Thermochronology of allochtonous terranes in Ecuador: unraveling the accretionary and post-accretionary history of the Northern Andes. Tectonophysics, 399, $195-220$.

Stone, B., 1946. Stichocassidulina, a new genus of foraminifera from norhwestern Peru. Journal of Paleontology, 20, 59-61.

Taipe, E., Jaillard, E., Jacay, J., 2004. Estratigrafia y evolución sedimentológica de la serie del Cretáceo superior de la Península de Paita. Boletin de la Sociedad Geológica del Perú, 97, 7-27, Lima.

Thalmann, H.E. 1946. Micropaleontology of Upper Cretaceous and Paleocene in western Ecuador. American Association of Petroleum Geologists Bulletin, 30, 337-347, Tulsa.

Toro A., J., Jaillard, E., 2005. Provenance of the Upper Cretaceous to Upper Eocene clastic sediments of the Western Cordillera of Ecuador: Tectonic and geodynamic implications. Tectonophysics, 399, 279-292.

Tschopp, H.J., 1948. Geologische Skizze von Ekuador. Bulletin de l'Association Suisse de géologue et Ingénieurs du Pétrole, 15, 48, 14-45.

Vaca, W., 2005. Sedimentología, petrología y tectónica de las secuencias cretácicas entre Ingapirca y Pindilig, provincia de Cañar. Tesis Ingeniero Escuela Politécnica Nacional, Quito, 106 pp.

Vallejo, C., Spikings, R.A., Luzieux, L., Winkler, W., Chew, D., Page, L., 2006. The early interaction between the Caribbean Plateau and the NW South American Plate. Terra Nova, 18, 264-269.

Walaszczyk, I., Odin, G.S., Dhondt, A.V., 2002. Inoceramids from the upper Campanian and lower Maastrichtian of the Tercis section (SW France), the Global Stratotype Section and Point for the Campanian-Maastrichtian boundary; taxonomy, biostratigraphy and correlation potential. Acta Geologica Polonica 52, 269-305. 